\title{
Perspektywa produkcyjna w badaniach polskiego filmu dokumentalnego
}

\author{
IWONA MOROZOW
}

\section{Stan badań i refleksja}

Zarówno anglosaska ${ }^{1}$, jak i polska tradycja badań nad kulturą produkcji ${ }^{2}$ rozważa przede wszystkim komunikaty dotyczące filmu fabularnego, spychając dokument w sferę przedsięwzięć, które z perspektywy rynkowej nie wydają się wystarczająco ciekawe. Do podobnego wniosku dochodzi Małgorzata Smoleń, autorka jednego z nielicznych w ostatnich latach artykułów (analizuje w nim dorobek studiów „Kronika” i „Wir”) podejmujących temat produkcji dokumentów po 1989 r. Smoleń zwraca uwagę, że w piśmiennictwie dotyczącym dokumentalistyki dominują prace skupiające się na wartościach artystycznych, na twórcach lub nurtach ${ }^{3}$. Oczywiście w tej grupie zdarzają się wyjątki - warto w tym miejscu wspomnieć o wydanym niedawno Elementarzu Wytwórni Filmów Oświatowych ${ }^{4}$ opisującym szczegółowo historię tej instytucji. Interesujący jest również powiązany z książką artykuł jednego z jej autorów, który wnikliwie, bazując na konkretnych przypadkach, bada tok produkcji wybranych filmów krótkometrażowych WFO z epoki gierkowskiej, sięgając po zakulisowe historie, anegdoty oraz źródła archiwalne. Całość doskonale wprowadza w niuanse pracy filmowca, ukazując konteksty społeczne i polityczne ${ }^{5}$. Innym ciekawym przykładem jest tekst Krzysztofa Kopczyńskiego o dystrybucji polskiego filmu za granicą opisujący proces finansowania dokumentów w lokalnych i europejskich warunkach z podkreśleniem ważności strategii promocyjnej już w okresie rozwoju projektu ${ }^{6}$. Autor konkluduje, że praca nad filmem dokumentalnym to długotrwały proces z niepewnym wynikiem i proponuje polskiemu dokumentaliście przemyślenie uwagi Seana McAllistera: Jeśli jesteś w stanie znaleźć łatwiejszy sposób na życie - zrób to ${ }^{7}$. Warto też wspomnieć o artykule Michała Piepiórki na temat głośnego Fuck for Forest Michała Marczaka (2012). Autor, analizując strategię promocyjną filmu (z uwzględnieniem rynku polskiego i zagranicznego), rekonstruuje społeczny i medialny obieg dzieła, stanowiący (jak pisze za Marcinem Adamczakiem) istotny element łańcucha produkcyjnego w kontekście tworzenia sensów i artystycznych praktyk znaczeniotwórczych ${ }^{8}$.

Oprócz przywołanych artykułów, można także wspomnieć o dwóch publikacjach podręcznikowych dla przyszłych twórców dokumentów (opisują one szczegółowo etapy pracy nad projektem i dostarczają wielu wskazówek praktycznych ${ }^{9}$ ), a także o publikacjach z kręgu antropologii kulturowej, w ramach której spora część 
praktyki badawczej (zwłaszcza w tradycji anglosaskiej) skupia się na realizacjach dokumentów etnograficznych i refleksji wokół tego typu przedsięwzięć ${ }^{10}$. Podejścia te, jakkolwiek interesujące, nie są w stanie w mojej opinii zastąpić całościowych badań realiów produkcyjnych wybranego gatunku filmowego, uwzględniających wiele zależności z nimi związanych.

W latach 2016-2019 uczestniczyłam w pracach zespołu realizującego projekt Proces tworzenia dzieła filmowego oraz jego uwarunkowania organizacyjno-ekonomiczne w perspektywie badań kultury produkcji (kierownik dr hab. Marcin Adamczak). W części dotyczącej społecznego wymiaru procesu tworzenia dzieła filmowego nasz zespół zakładał połączenie kilku metod badawczych: ustrukturyzowanych, pogłębionych wywiadów z producentami i kierownikami produkcji, uzupełnionych o ankietę, oraz opisu doświadczeń zebranych przez studentów szkół filmowych (przeszkolonych pod kątem etnograficznym) podczas staży na planach filmowych (w formie tzw. dzienników emocjonalnych). W wyniku komplikacji związanych z dostępem do środowiska, mimo określonego pola badawczego ograniczającego się do produkcji fabularnych, postanowiliśmy je nieco rozszerzyć. Wspomniane problemy były związane (między innymi) z obawami ze strony branży o rozpowszechnianie niechcianych informacji, ale również z zaniepokojeniem studentów, którzy spodziewali się pewnych konsekwencji w związku z opisywaniem zakulisowych tajemnic. Ostatecznie zespół badaczy został powiększony o osoby, które już pracują w branży na stanowiskach asystenckich, przygotowanych do badań etnograficznych w ramach prowadzonych przeze mnie warsztatów. W efekcie otrzymaliśmy kilkanaście relacji, pochodzących również z planów produkcji dokumentalnych, i postanowiliśmy je uwzględnić w analizie, która ostatecznie została opublikowana $\mathrm{w}$ formie książki ${ }^{11}$. W naszym odczuciu to poszerzenie pola badawczego zapewniło dodatkowy kontekst analityczny, który pozwala odpowiedzieć na pytanie, czy istnieją głębsze różnice wynikające ze specyfiki tworzenia określonego rodzaju filmu, czy też podziały są zasadne wyłącznie w warstwie poetyki tekstualnej. Wprawdzie zajmowaliśmy się głównie filmami fabularnymi, ale uwzględnienie innych produkcji oferowało kontekst porównawczy. Zaprezentowany obraz wymaga jeszcze uzupełnienia i dalszego postępowania, które głębiej zbadałoby specyfikę pracy na planie filmu dokumentalnego, analizując chociażby szczegółowo i na konkretnych przykładach etapy łańcucha produkcyjnego (development, preprodukcję, okres zdjęciowy, postprodukcję, dystrybucję i promocję) i rozpatrując je zarówno w kontekście społecznym (pracujący-tworzący ludzie, relacje na planie), jak i rynkowym (finansowanie, strategie dystrybucyjne i promocyjne).

Tak zarysowane pole badawcze zostanie w niniejszym artykule poddane analizie na podstawie dokumentów branżowych, wybranych baz filmowych oraz przykładów ze wspomnianych dzienników emocjonalnych ${ }^{12}$ oraz wywiadów etnograficznych z twórcami i producentami filmów dokumentalnych, a także w oparciu o własne doświadczenia twórcze ${ }^{13}$. Pochylając się nad problematyką procesu tworzenia i powiązanego z nim kontekstu zrekonstruowanego za pomocą etnograficznego detalu w mikrohistoriach, tekst ten wpisuje się, jak sądzę, w nurt współczesnych badań nad kulturą produkcji filmowej. 
Po szesnastej edycji festiwalu Millenium Docs Against Gravity, Stowarzyszenie Filmowców Polskich - za Tadeuszem Sobolewskim - ogłosiło „nową falę polskiego dokumentu". Optymistyczny ton został poparty statystykami, które wskazywały na ponad 50-procentowy wzrost oglądalności i nadzwyczajne zainteresowanie widzów filmami polskich twórców oraz wysokimi walorami artystycznymi w kontekście nawiązywania młodych autorów do mistrzów polskiego dokumentu: Kazimierza Karabasza, Krzysztofa Kieślowskiego oraz Marcela i Pawła Łozińskich ${ }^{14}$. Niestety, wydaje się, że ani osiągnięcia festiwalowe, ani twórcze nie są w stanie zmienić dość trudnej sytuacji polskiego dokumentu przekładającej się na umiarkowane warunki finansowania i dość zaniedbany rynek dystrybucyjny. Wszystko to sprawia, że - jak powiedział w wywiadzie jeden z moich respondentów, młody producent kilku filmów: produkcja dokumentalna jest czymś dla poczatkujących producentów, ponieważ to nie jest sposób na wywindowanie firmy. W dalszej części rozmowy respondent zwrócił uwagę na pozorną łatwość tego rodzaju produkcji, co przyciąga początkujących twórców, a przez co sam rozumie przede wszystkim prostsze aplikowanie z uwagi na mniejszy budżet. Jednak jeżeli chodzi o samą produkcję, okazuje się ona zwykle trudniejsza, ponieważ niesie ze sobą większe ryzyko. Z uwagi na długoterminowy charakter produkcji łatwiej również o „wypalenie” i zmęczenie materii ${ }^{15}$. Niszowość dokumentu ${ }^{16} \mathrm{z}$ jednej strony przyciąga, stwarzając szansę na początek kariery w branży, umożliwiając zrealizowanie pierwszych projektów za stosunkowo niewielkie pieniądze, natomiast $\mathrm{z}$ drugiej strony nie daje takich szans na rozwój (firmy, kariery), jakie oferuje film fabularny. W efekcie po zakończeniu wywiadu, usłyszałam anegdotę z jednego z branżowych spotkań dla producentów (off the record), na którym padło stwierdzenie prowadzącego, że po prostu odradza się produkowania dokumentów.

\section{Finanse i dystrybucja}

Warunki finansowe, sprawiające że - mówiąc kolokwialnie - „na dokumencie jest trudniej zarobić", to niewątpliwie tylko jeden aspekt problemu. Drugim jest owa niszowość, która sprawia, że widz dokumentu należy do wąskiej, elitarnej grupy odbiorczej i dlatego dużo trudniej zaistnieć i zostać docenionym w branży. Zresztą w tej materii niewiele dają nawet nagrody na festiwalach, co obrazuje choćby statystyka dokumentów, które otrzymują przepustkę do sal kinowych w regularnej dystrybucji, nie wspominając już o liczbie widzów, która znacznie odbiega od oglądających filmy fabularne. Oczywiście naturalnym kierunkiem dystrybucji jest telewizja, co jednak jedynie potwierdza ograniczenie pola eksploatacji dla dokumentu.

Obecne warunki finansowania polskiej produkcji dokumentalnej jawią się jednak nad wyraz korzystnie. Oczywiście, podstawowym kierunkiem dla większości producentów i twórców jest Polski Instytut Sztuki Filmowej, który oferuje środki zarówno na rozwój projektu (priorytet I i priorytet VIII w koprodukcji polsko-niemieckiej ${ }^{17}$ ), jak i samą produkcję. Ten drugi element może być finansowany w ramach czterech priorytetów w zależności od charakteru filmu. W ramach priorytetu III, czyli dofinansowania produkcji filmów dokumentalnych, budżet w 2019 r. wyniósł $10 \mathrm{mln}$ złotych (fabuła $52 \mathrm{mln}$ zł). Ponadto o środki na produkcję dokumentów można wnioskować w priorytecie VI w przypadku koprodukcji mniejszościowych (budżet 2019 - 10 mln zł), w priorytecie VII w przypadku filmów 
nowatorskich, charakteryzujących się niekonwencjonalną formą i technikami (2019 - 1 mln złotych); i w ramach Polsko-Niemieckiego Funduszu Filmowego w ramach priorytetu VIII (2019 - 650000 złotych). W ramach większości kategorii można wnioskować o finansowanie dla filmów średnio- i długometrażowych, poza priorytetem VI przeznaczonym dla pełnych metraży, natomiast priorytet III stwarza możliwość również dla dokumentów krótkometrażowych. Kwoty dofinansowania filmów dokumentalnych w 2019 r. wahają się od 100 tys. dla krótkometrażowych filmów autorskich (w ramach priorytetu III) do 1,5 mln dla pełnometrażowych filmów historycznych i co ważne, zasady finansowania są zbieżne z fabułą, gdzie kwota finansowania nie może przekroczyć 50 proc. budżetu lub 70 proc. w przypadku filmów trudnych ${ }^{18}$. Jako komentarz dodam opinię producenta, który powiedział: W przypadku dokumentu akurat niewiele trzeba, żeby udowodnić, że film jest trudny ${ }^{19}$.

Poza PISF początkujący twórcy dokumentu do czterdziestego roku życia mogą się starać o pieniądze na „pierwszy dokument” ze Studia Munka (instytucja działająca w strukturach Stowarzyszenia Filmowców Polskich), które dofinansowuje do dziesięciu krótkich filmów rocznie (10-15 minut). Kolejną możliwością są Fundusze Regionalne, które najczęściej wspierają projekty mające już inne źródło finansowania oraz są szeroko powiązane $z$ regionem ${ }^{20}$. Nieco inne, przeznaczone na większe projekty, są programy Kreatywna Europa i Euroimages. Ten pierwszy jest na development dla „kreatywnych dokumentów” przeznaczonych do dystrybucji kinowej, telewizyjnej i VOD oraz na wsparcie produkcji i dystrybucji projektów międzynarodowych. Drugi fundusz dotyczy wyłącznie koprodukcji filmów dokumentalnych dłuższych niż 70 minut ${ }^{21}$. Kolejnym istotnym elementem jest finansowanie przez telewizję i tutaj warto przede wszystkim wymienić: TVP, HBO, Planete, Discovery, Canal+, Arte i Polsat, który - jak deklarował Radosław Sławiński podczas Krakowskiego Festiwalu Filmowego w 2019 r. - jest bardzo zainteresowany współpracą z polskimi dokumentalistami, choć zaznacza, że nie interesują go raczej typowe produkcje festiwalowe ${ }^{22}$. Telewizje są najczęściej dystrybutorami produkcji, co przy okazji finansowania pozwala na stworzenie platformy do szerszego zaprezentowania własnego filmu i dla wielu twórców, ze względu na ograniczony rynek kinowy, są to warunki korzystne.

Ostatnie, dość nietypowe, jest finansowanie pozasystemowe. Głośnym przykładem był film braci Sekielskich Tylko nie mów nikomu (2019), którym przez crowdfunding udało się zgromadzić kwotę 450 tys. złotych, a następnie, dzięki umieszczeniu filmu na platformie YouTube uzyskać w krótkim czasie ponad 22,5 mln wyświetleń ${ }^{23}$. Oczywiście szansę na takie finansowanie stwarzał ważny społecznie i szeroko dyskutowany problem pedofilii, co znaczy, że crowdfunding nie jest możliwy dla każdej produkcji dokumentalnej. Inną formą pozasystemowego pozyskiwania środków są naukowe projekty badawcze, które mają dość silną tradycję za granicą (np. w Wielkiej Brytanii oraz USA), jednak w Polsce jest to zjawisko marginalne ${ }^{24}$. Takie finansowanie daje twórcy względną wolność, jednocześnie utrudniając potencjalną drogę do oficjalnych kanałów dystrybucji. Oczywiście, zarówno w kraju (np. festiwal Oczy i Obiektywy), jak i za granicą (np. RAI Film Festival) odbywają się wydarzenia poświęcone naukowemu kinu antropologicznemu i najczęściej to na owych festiwalach droga takich filmów się kończy, ewentualnie stwarzając szanse na krążenie w środowisku akademickim ${ }^{25}$. 
Warto również w tym miejscu wspomnieć o innych, pozafinansowych formach wsparcia, z których najbardziej znacząca branżowo jest Doc Lab Poland oferująca tzw. know-how w zakresie realizacji, dystrybucji i promocji. Jak można przeczytać na stronie www: jest to kompleksowy program rozwoju projektów filmowych organizujący warsztaty (np. prowadzące do prezentacji-pitchingu), konsultacje indywidualne i panele dyskusyjne. Wszystko to ma na celu wzmocnienie wartości artystycznej wybranych projektów, przy jednoczesnym zwiększeniu ich potencjału festiwalowego i dystrybucyjnego. (...) promocję filmu dokumentalnego wśród widzów polskich kin i działania na rzecz wprowadzania petnometrażowych dokumentów do kin, ich większej ekspozycji w kanałach telewizyjnych oraz promocji polskiego dokumentu na świecie ${ }^{26}$. Program składa się z dwóch komponentów: wspierających rozwój projektu (Doc Lab Start) oraz filmów znajdujących się już w fazie produkcji (Doc Lab Go). Program nie przewiduje uzyskania bezpośredniego dofinansowania, ale umożliwia pokrycie kosztów podróży i udziału w wydarzeniach branżowych, bony na postprodukcję itp.

Należy jeszcze wspomnieć o dystrybucji kinowej, która w przypadku filmów dokumentalnych nie jest typowym zwieńczeniem łańcucha produkcyjnego. Według portalu filmpolski.pl w 2018 r. powstało około 80-100 średnio- i długometrażowych filmów dokumentalnych ${ }^{27}$. Jeśli to zestawić z liczbą polskich filmów dokumentalnych, które w ciągu ostatnich kilku lat dostały się do krajowej dystrybucji kinowej, statystyka nie okaże się już tak zadowalająca. W 2015 były to bowiem 4 filmy, w 2016 - 6, w 2017 - 7, w 2018 - 5, natomiast w 2019 na ekrany wszedł jeden film dokumentalny, a w drugiej połowie roku planowany jest jeszcze jeden ${ }^{28}$. Warto to zestawić z dokładniejszymi danymi, obrazującymi widownię i wpływy z dystrybucji kinowej w ciągu wspomnianych ostatnich kilku lat (patrz Tabela ${ }^{29}$.

$\mathrm{Na} 23$ produkcje dystrybuowane w latach 2015-2019 ${ }^{30}$, zaledwie dwie przyniosły wpływy przekraczające milion złotych. Pierwsza trójka mogłoby świadczyć, że sukces jest przede wszystkim w zasięgu dokumentów poświęconych tematom religijnym i historycznym ${ }^{31}$. Warto też zwrócić uwagę na obecność na polskim rynku dystrybutorów, którzy włączają do swojego portfolio filmy dokumentalne, jak: Solopan, Mayfly, Against Gravity oraz firmy o wyrazistym profilu tematycznym: Rafael i Kondrat Media.

Zaprezentowane w tej części artykułu informacje mają oczywiście charakter pobieżny. Potrzebne jest bowiem dokładne opisanie i przeanalizowanie warunków finansowych polskiego dokumentu, które zawierałoby zestawienie materiałów branżowych z konkretnymi realizacjami. Ponadto konieczne jest zwrócenie uwagi na często ignorowane pozafinansowe formy wsparcia, oferujące cenną wiedzę umożliwiającą umiejętne przeprowadzenie projektu. Warto też zwrócić uwagę na aspekt dystrybucji i promocji, analizę danych box office'u oraz indywidualnych strategii dystrybutorów i producentów.

\section{Realizacja filmu}

Ostatnim problemem, który chciałabym poruszyć, jest specyfika warunków produkcyjnych filmu dokumentalnego. Jest to kwestia jedynie wspominana w literaturze przedmiotu, zazwyczaj w formie anegdotycznej (niekiedy wspomina się zabawne lub prowokacyjne sytuacje, które doprowadziły do powstania konkretnej 


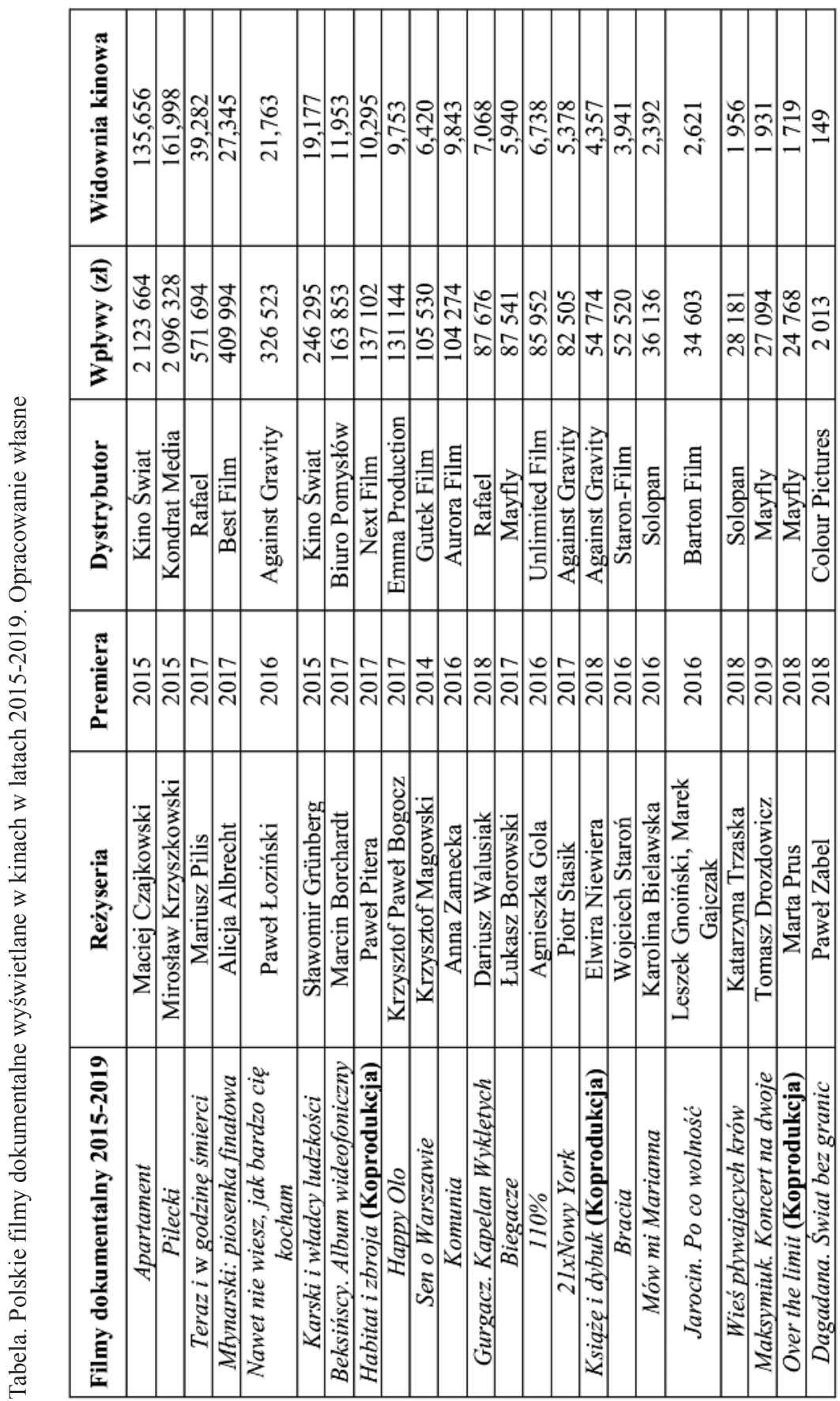


sceny w filmie ${ }^{32}$ ). Takie przekazy mają charakter fragmentaryczny i rozproszony, nie skupiają się bowiem na problematyce społecznego funkcjonowania planu zdjęciowego. Jednak należy pamiętać o kulturotwórczym kontekście tych anegdot, o ich roli i wartości zarówno dla środowiska filmowego, jak również dla badaczy ${ }^{33}$. Jest to jednak wyłącznie drobny przejaw funkcjonowania planu zdjęciowego, który nie definiuje całości.

W związku z tak zarysowaną tematyką chciałabym zwięźle nakreślić charakterystykę produkcji dokumentu. Jednocześnie zaznaczam, że ten rodzaj filmu cechuje ogromna różnorodność i nie sposób na łamach tego artykułu opisać wszystkich jego odmian, dlatego skoncentruję się na kameralnej, „klasycznej”, „czystej” formie, opartej na obserwacji i wywiadach. Zupełnie inną formę produkcji ma bowiem film eksperymentalny wykorzystujący nowe technologie multimedialne, jak również taki, który stanowi rodzaj hybrydy zrealizowany głównie w warunkach studyjnych. W przypadku tego typu przedsięwzięć łatwiej o analogie z wysokobudżetową produkcją filmu fabularnego, przy uczestnictwie dużej ekipy filmowej i rozbudowanym, wieloaspektowym etapie postprodukcyjnym.

Jak wynika z wywiadów, dzienników terenowych oraz mojego doświadczenia podstawowa ekipa dokumentalistów składa się z mniej niż dziesięciu osób (w przeciętnej fabule w warunkach polskich jest to najczęściej około 80 osób). Główny trzon stanowi reżyser, operator, dźwiękowiec i kierownik produkcji, jednak wiele z tych funkcji może być łączonych. Reżyser bywa jednocześnie operatorem (tzw. reżop), niekiedy operator (czasem i reżyser) zajmuje się rejestracją dźwięku na planie, a z obecności kierownika produkcji można ostatecznie zrezygnować, jeżeli budżet tego wymaga. Oczywiście inne funkcje są odpowiednio dodawane w zależności od wymagań konkretnej produkcji. I tak, w jednym ze wspomnianych dzienników, w związku z realizacją zdjęć za granicą, zaistniała potrzeba ściągnięcia na plan tłumacza. Mogłoby się zatem wydawać, że czasy direct cinema dokument ma już za sobą; jednak jak wynika z przeprowadzonych wywiadów, ekipa planowa w jednym przypadku liczyła jedną lub dwie osoby (w zależności od okresu zdjęciowego), w drugim jedną, w trzecim dwie - trzy, a ostatnia produkcja wyjazdowa aż sześć; okazuje się zatem, że ta założycielska tradycja jest wciąż żywa. Ponadto, z uwagi na długotrwały charakter produkcji, ekipa filmowa może się zmieniać, co potwierdza fragment dziennika terenowego: zdjęcia składały się z sześciu tur realizowanych o różnych porach roku. Grupa zdjęciowa składała się z reżysera, producenta/kierownika produkcji, operatora obrazu, operatora dźwięku, thumacza (...), asystenta producenta. Na przestrzeni tylu wyjazdów pomiędzy turami musiała występować té rotacja ludzi. Dwukrotnie zmienit się operator obrazu, trzykrotnie ttumacz, raz dźwiękowiec i raz asystent produkcji ${ }^{34}$.

Chciałabym jeszcze zaznaczyć, że przytaczana liczba osób związanych z poszczególnymi realizacjami nie odnosi się do produkcji offowych, realizowanych bezbudżetowo, lecz tych, które w prawie każdym przypadku otrzymały środki na produkcję z Polskiego Instytutu Sztuki Filmowej. Mała ekipa jest oczywiście korzystna z kilku powodów. Po pierwsze dopasowuje się do rodzaju dokumentu, umożliwia uzyskanie odpowiedniej bliskości z bohaterami. Po drugie, jest nią łatwiej zarządzać i minimalizuje problemy związane z grą o władzę i dominację (jak można przeczytać w jednym z dzienników: ekipa była mała, więc pola do uprawiania ,polityki” właściwie nie było ${ }^{35}$ ). Po trzecie, z uwagi na specyficzną reali- 
zację zdjeć dokumentalnych, bywa bardziej mobilna. Wreszcie, po czwarte, znacznie ogranicza koszty produkcji (w porównaniu $z$ fabułą). W efekcie istnieje ogromna różnica w doświadczaniu planu zdjęciowego filmu fabularnego i dokumentalnego; przy czym ten drugi często przypomina formę wspólnego spędzania czasu, czyli mozolnego wyczekiwania (jeden z moich studentów, trafiwszy po raz pierwszy na plan dokumentu przyznał, że zupełnie nie tak to sobie wyobrażał).

Długotrwałość okresu zdjęciowego powoduje, że nie jest łatwo ustalić sztywny harmonogram zdjęć, a przy ograniczeniu się do metody obserwacji - również „rozciągnięcie" w czasie, co w jednym z analizowanych przypadków skutkowało siedmioletnim planem zdjęciowym. Oczywiście, długotrwałość zdjęć przekłada się również na ilość materiału, który następnie trzeba przejrzeć pod kątem montażu. Zresztą etap postprodukcji w realizacji dokumentalnej również jest dość wymagający z uwagi na szukanie historii w ogromnej ilości godzin nagrań obserwacyjnych. Etap ten może się jeszcze bardziej skomplikować, gdy film jest kręcony za granicą i bohaterowie mówią w języku innym niż w kraju produkcji. Wówczas sporą część materiału należy przetłumaczyć lub zdecydować się na współpracę z montażystą znającym dany język. Problem ten pokazuje poniższy fragment dziennika (jednocześnie warto zaznaczyć, że ani reżyser, ani producent nie mówili w obcym języku i na planie korzystali z tłumacza, co jeszcze bardziej komplikowało etap montażu): Wyjątkowa uwage należy zwrócić również na montaż. Wszystkie materiały sa oczywiście w języku x. Twórcy mieli zatem do wyboru albo całość materiału przettumaczyć i pracować z polskim montażysta albo pracować z montażysta z kraju X. Obydwie opcje miaty swoje plusy i minusy. Budżetowo obydwie opcje byty mniej więcej takie same - przetlumaczenie materiałów vs. pobyt twórców w kraju X podczas montażu (ewentualnie pobyt tamtego montażysty w Polsce). Wybrano opcję pośrednią: materiały zostały przettumaczone na poziomie bardzo ogólnym (jedynie informacja, o czym rozmawiaja bohaterowie $w$ danej scenie) a montażem na odległość (wspótpraca on-line) z montażystka z kraju X-(...) Montaż nadal trwa. Wspótpraca polega na tym, że reżyser pracuje nad materiałami $w$ Warszawie a montażystka w kraju X. Spotykają się na Skype'ie, a montażystka co jakiś czas wysyła pliki ze zmontowanymi (wg wskazań reżysera) scenami ${ }^{36}$.

Z omawianą specyfiką realizacji zdjęć wiąże się jeszcze jeden element komplikujący pracę przy tego typu projektach. Jest nim realizacja zdjęć już na etapie developmentu, czyli jeszcze przed uzyskaniem finansowania (działo się tak we wszystkich czterech wspomnianych wyżej produkcjach). Powody i niuanse tego typu decyzji doskonale tłumaczy poniższy fragment dziennika: Rozwój projektu (zdjęcia próbne, pisanie scenariusza, research, tworzenie trailera, zdobywanie koproducentów) trwat około roku. Po zakończeniu developmentu o produkcję filmu trzeba byto się starać... 2 lata. Film dwukrotnie nie uzyskat dofinansowania na produkcję w PISF. Głównym powodem było to, że komisja ekspertów nie zgadzała się z zaproponowanym kształtem artystycznym reżysera i producenta (zbiorowy bohater, zdjęcia obserwacyjne, brak jasnego konfliktu). Walory filmu zostały jednak ostatecznie docenione przez Dyrektora PISF Magdalenę Srokę, która przyznała dotacje z własnej puli. Po wygranej potyczce z PISF należało nastęnie podpisać umowe z TVP 2. Tutaj niestety również pojawit się problem. Byt koniec (...) roku $i$ w zwiazku ze zmianami kadrowymi w spółkach państwowych procedowanie umowy koprodukcyjnej pomiędzy Telewizja a producentem po roku pracy trzeba 
było zaczać od początku. Podczas tego dtugiego procesu producent i reżyser pracowali caly czas nad filmem, jeżdżac do miejscowości X bez środków na produkcje filmu. Chodziło o to, aby nie stracić bezpowrotnie historii bohaterów ${ }^{37}$.

Biorąc pod uwagę wymóg opracowania scenariusza przy składaniu wniosku o finansowanie, podjęcie decyzji o zdjęciach obserwacyjnych powoduje, że w początkowym stadium projektu są one często realizowane bez budżetu, $\mathrm{z}$ własnych środków. Oczywiście szansą na ominięcie takich problemów jest staranie się o dofinasowanie developmentu, jednak należy zaznaczyć, że środki finansowe, chociażby $\mathrm{z}$ budżetu PISF, są tu znacznie ograniczone ${ }^{38}$. Jeden z moich respondentów zaznaczył, że nawet nie próbuje się o nie starać, bo konkurencja jest ogromna, a szanse nikłe i lepiej jest odczekać i składać od razu wniosek dotyczący produkcji ${ }^{39}$.

Cechą charakterystyczną dla produkcji dokumentalnych jest ogromna rola czynników etycznych i związanych z nią sytuacji konfliktowych oraz kosztów emocjonalnych. Zepsuta kamera, rozbity obiektyw, rozładowany akumulator, kłótnia w zespole lub z miejscową ludnością, choroby, kończący się budżet czy wyjątkowo trudne warunki zdjęć plenerowych to sytuacje, które mogą zdarzyć się zarówno na planie fabuły, jak i dokumentu. Produkcje drugiego typu są jednak obarczone dodatkowym ryzykiem i zwiększoną odpowiedzialnością. Wątek etyki, porusza poniższy fragment dziennika: To, czy twórcy maja prawo „oszukiwać” w filmie dokumentalnym oraz to, czy pracownik w ekipie zdjęciowej może odmówić wykonania swoich obowiązów, jeśli wykraczaja one poza jego granice moralne, pozostawiam czytelnikowi. Moge powiedzieć jednak na pewno, że typologia konfliktu dotyczacego sfery moralnej realizowanego filmu dokumentalnego była demobilizująca, tworzaca bardzo wiele napięć, krótko mówiąc destrukcyjna i w żaden sposób niemotywująca do pracy. Byliśmy wtedy jak w stynnym eksperymencie Philipa Zimbardo - zamknięci w hermetycznej rzeczywistości, podzieleni na złych oprawców i niewinne ofiary ${ }^{40}$.

Aby ukazać wagę tego problemu, przytoczę przykłady z własnej praktyki oraz wymiany doświadczeń z innym twórcą podczas nieformalnej rozmowy. Jeśli film dokumentalny opowiada o bohaterach ,z krwi i kości”, odsłaniając kulisy prywatności i nierzadko dotykając sfer niezwykle intymnych, na dokumentaliście spoczywa ogromna odpowiedzialność związana z przedstawianiem wizerunku tych ludzi. Ponosi on też wiążące się z tym konsekwencje. Podczas własnej realizacji współpracowałam z dość trudnym środowiskiem bezdomnych mężczyzn, alkoholików, którzy realizowali się przez tworzenie amatorskich filmów o losach osób społecznie wykluczonych. Chciałam, aby realizacja opowiadała o zmianie przez sztukę zobrazowanej przy pomocy indywidualnych historii. Film był realizowany przez dwa lata, poprzedzony kilkuletnimi badaniami terenowymi, podczas których starałam się zdobyć zaufanie moich bohaterów. W związku z przyjęciem wykładni antropologicznej, oparłam się na współpracy, chcąc, aby prezentowany głos był bardziej „nasz” niż „mój”. Efektem był przekaz wyśrodkowany, dialektyczny, który umożliwiał współtworzenie wizerunku osób bezdomnych. Przyjęta wysoka etyka pracy musiała jednak skutkować wieloma pominięciami w przedstawianej historii. Wielokrotnie rozważałam włączenie materiałów przedstawiających sytuacje kryzysowe w życiu moich bohaterów, które niewątpliwie „zagrałyby filmowo”, ale podejmując taką decyzję, przekroczyłabym ustalone granice etyczne wypowiedzi. Nie chodziło jednak o fałszowanie i upiększanie rzeczywistości na siłę, lecz omijanie wątków, które mogły zaszkodzić wizerunkowi już mocno napiętnowanej grupy spo- 
łecznej. W mojej opinii film nie byłby w stanie w wystarczająco pogłębiony sposób oddać wielowarstwowości problemu alkoholizmu, a przez to nie mógłby przedstawić wszystkich ważnych aspektów. Z podobnym dylematem spotkał się twórca, który we wspomnianej nieformalnej rozmowie zapytał mnie o radę w kwestii uwzględnienia wątku alkoholizmu w swoim filmie, opowiadającym również o wykluczonej społeczności. Z jednej strony „picie” stanowiło integralny element funkcjonowania ludzi i przez to istotną cechę tej społeczności, natomiast z drugiej mogłoby pociągnąć za sobą pewne konsekwencje dla ich dalszych losów. W takich przypadkach kwestia stawiania pytań, dyskutowania jest konieczna i sprawia, że na jego barkach spoczywa ogromna odpowiedzialność za film i ludzi, o których opowiada. Z omawianym wątkiem wiążą się oczywiście ogromne koszty emocjonalne, które jednak dla mnie dużo silniej ujawniają się w momencie zakończenia zdjęć.

„Depresja poplanowa” ${ }^{41}$ to kolejna, charakterystyczna cecha pracy w branży, jednak w przypadku filmu dokumentalnego dochodzi jeszcze element swoistego „wyjścia z terenu" ${ }^{42}$, by posłużyć się analogią z zakresu badań etnograficznych. W książce Metody badań terenowych Hammersley i Atkinson tak piszą o tym specyficznym doświadczeniu: ...wyjazd z terenu badań łączy się z dużym przeżyciem emocjonalnym. Ludzie $w$ danym środowisku moga czuć się zdezorientowani, słyszac, że etnograf, który tak dtugo byt częścia ich codziennego życia, nagle wyjeżdza. Informatorzy musza oswoić się z myśla, że osoba, która zaczęli uznawać za swojego przyjaciela, ponownie zmieni się w kogoś obcego. Również dla etnografa takie przeżycie może być bardzo bolesne ${ }^{43}$.

Długotrwałe, czasem niezwykle intymne zdjęcia powodują, że nie sposób nie zaangażować się w życie swoich bohaterów. Jednocześnie chciałabym zaznaczyć, że wyjście z terenu wcale nie jest charakterystyczne (jak mógłby wskazywać cytowany fragment) dla badań/zdjęć wyjazdowych, bowiem nawet przy realizacji w miejscu zamieszkania przychodzi czas, kiedy projekt się kończy wraz z codziennym bywaniem w środowisku, co wywołuje nierzadko podobną konsternację bohaterów, jak i dylematy ze strony filmowca.

Inną analogią między pracą antropologa w terenie a dokumentalisty na planie zdjęciowym jest wątek ,wzajemności” ${ }^{44}$, który nie był jeszcze poruszany w literaturze przedmiotu, a w mojej opinii stanowi dość ważną część praktyki. Aby to zobrazować, przytoczę sytuację z zajęć warsztatowych z filmu dokumentalnego, podczas których prowokacyjnie zadałam studentom pytanie: czy bohaterom dokumentu powinno się płacić? Rozpoczęła się burzliwa dyskusja, w której przeważały głosy o niestosowności takiej praktyki. Wśród argumentów padały przede wszystkim opinie o „sprzedawaniu własnego życia” i etycznej niestosowności takiego zachowania. Oczywiście analogiczne pytanie dotyczące fabuły nie wzbudziłoby żadnych kontrowersji, bo przecież bohaterowie dokumentu właściwie „nic nie robią" poza poświęcaniem własnego czasu, a to jedynie pokazuje, że społeczny status dokumentu jest aksjologicznie identyfikowany jako bardziej „czysty”, a przez to niechętnie kojarzony z wynagrodzeniem. W badaniach własnych (wywiady) zdania są bardzo podzielone i nie da się jednoznacznie odpowiedzieć na to pytanie. Wszystko zależy od rodzaju produkcji, środowiska, bohaterów, tematu i oczywiście warunków finansowych. Dla przykładu, w moim projekcie filmowym, który otrzymał środki dopiero na końcowym etapie zdjęć, nie zdecydowałam się wynagradzać bohaterów (było ich trzech), natomiast odwdzięczałam się im drob- 
nymi przysługami i „nagrodami” w postaci na przykład wspólnych wyjść na mecz piłki nożnej. Podobną taktykę obrał przepytywany producent, który dla filmowanej społeczności przywoził szeroko pojęte ,prezenty”, jak sam to określił w wywiadzie. Inną sytuacją może być film znajomej reżyserki na temat nowatorskiego cyrku, który w opinii filmowanych może dla nich stanowić formę promocji i w związku z tym „wzajemność” zostaje zachowana. Spośród przeprowadzonych wywiadów tylko w jednym przypadku padła jednoznaczna deklaracja o wynagrodzeniu dla bohatera filmu. Na pytanie o powód takiej decyzji, reżyser wskazał, że bohater poświęcił wiele czasu ekipie i był bardzo zaangażowany w realizację zdjęć. W dalszej rozmowie okazało się, że umowa finansowa ostatecznie uchroniła producenta przed katastrofą, jaką byłoby cofnięcie prawa do wykorzystania wizerunku. Bowiem $\mathrm{w}$ trakcie realizacji bohaterowie się pokłócili i zerwali relację, co w efekcie doprowadziło do nalegania na usunięcie scen $\mathrm{z}$ udziałem jednej $\mathrm{z}$ osób (w rezultacie $g d y$ byśmy nie podpisali z nimi takiej umowy, to nie mielibyśmy filmu ${ }^{45}$, mówił respondent). Jednocześnie producent podkreślał, że jednym z czynników, które sprawiają, że produkcja dokumentalna jest o wiele bardziej ryzykowna niż fabuła, jest właśnie owa możliwość stosunkowo łatwego wycofania wspomnianej zgody: chodzi o to, że bohaterowie dokumentu w każdej chwili moga wycofać zgodę na wizerunek, a nawet jak nie wycofaja, to maja prawo pozwać producenta o naruszenie dóbr osobistych ${ }^{46}$ - mówił respondent.

$$
* * *
$$

Specyfika produkcji dokumentalnej sprawia, że twórcy i badacze muszą się zmierzyć z wieloma pytaniami, na które dopiero odpowiednie badania jakościowe mogłyby udzielić głębszej odpowiedzi. W tekście starałam się zaledwie przedstawić kilka z nich, podkreślając potrzebę starannego opisania finansowania tego typu produkcji, jak również przeanalizowania rynku dystrybucji. Opisanie warunków produkcyjnych ma wartość nie tylko wyjaśniającą dla filmoznawców i medioznawców, ale także dla przyszłych twórców filmów dokumentalnych, których w ten sposób można przygotować na problemy wiążące się z pracą na planie.

IWONA MOROZOW

${ }^{1}$ Zob. np.: J. T. Caldwell, Production Culture: Industrial Reflexivity and Critical Practice in Film and Television, Durnham 2008; Production Studies. Cultural Studies of Media Industries, red. V. Mayer, M. J. Banks, J. T. Caldwell, Routledge, New York - London 2009. ${ }^{2}$ Zob. np. M. Adamczak, Globalne Hollywood, filmowa Europa i polskie kino po 1989 roku. Przeobrażenia kultury audiowizualnej przełomu stuleci, słowo/obraz terytoria, Gdańsk 2010; tenże, Obok ekranu. Perspektywa badań produkcyjnych a spoleczne istnienie filmu, Wydawnictwo Naukowe UAM, Poznań 2014; A. Majer, A. Orankiewicz, A. Wróblewska,
Pieniadze-produkcja-rynek. Finansowanie produkcji filmowej w Polsce, Wydawnictwo Biblioteki Państwowej Wyższej Szkoły Filmowej, Telewizyjnej i Teatralnej, Łódź 2019; A. Wróblewska, Production studies w Polscestan badań, „Panoptikum” 2016, nr 16; taż, Rynek filmowy $w$ Polsce, Wydawnictwo Wojciech Marzec, Warszawa 2014; E. Zajiček, Film polski. Ekonomika i organizacja produkcji, Państwowe Wydawnictwo Naukowe, Warszawa 1983; tenże, Poza ekranem. Polska kinematografia w latach 1896-2005, Stowarzyszenie Filmowców Polskich, Warszawa 2009; tenże, Praca i film. Problemy ekonomiki pracy w produk- 
cji filmowej, Wydawnictwo PWSFTviT, t. I-II, Łódź 1997.

${ }^{3}$ M. Smoleń, Studia filmowe „Kronika” $i$,, Wir”, czyli kilka uwag na temat produkcji filmów dokumentalnych po roku 1989, ,Images” 2013, t. 13, nr 22, s. 59-60.

${ }^{4}$ M. Dondzik, K. Jajko, E. Sowiński, Elementarz Wytwórni Filmów Oświatowych, Wydawnictwo Wytwórnia Filmów Oświatowych, Łódź 2018.

${ }^{5}$ E. Sowiński, Produkcja filmu krótkometrażowego $w$ epoce gierkowskiej na przykładzie działalności Wytwórni Filmów Oświatowych, „Panoptikum” 2016, nr 16(23), s. 93-104.

${ }^{6}$ Zob. K. Kopczyński, Dystrybucja polskich filmów dokumentalnych $w$ świecie - smuga cienia, w: Wokó zagadnień dystrybucji filmowej, red. M. Adamczak, Wydawnictwo Biblioteki Państwowej Wyższej Szkoły Filmowej, Telewizyjnej i Teatralnej, Łódź 2015, s. 160-181.

${ }^{7}$ Tamże, s.180-181.

${ }^{8}$ M. Piepiórka, Dobry, zly i brzydki. „,Fuck for Forest" Michała Marczaka w obiegu społecznym i medialnym, „Images” 2017, t. XXI, nr 30, s. 111-134.

${ }^{9}$ Dla przykładu: G. Kędzielawska, Przewodnik dokumentalisty. Podstawy warsztatu. Skrypt, Wydawnictwo Biblioteki Państwowej Wyższej Szkoły Filmowej, Telewizyjnej i Teatralnej, Łódź 2016 lub B. S. Curran, Documentary Storytelling, Elsevier, Oxford 2011.

${ }^{10}$ Zob. np.: S. Pink, Etnografia wizualna. Obrazy, media $i$ przedstawienie $w$ badaniach, tłum. M. Skiba, Wydawnictwo Uniwersytetu Jagiellońskiego, Kraków 2009; taż red., Visual Interventions. Applied Visual anthropology, Berghahn Books, New York - London 2009; J. Ruby, Picturing Culture. Explorations of Film \& Anthropology, The University of Chicago Press, Chicago - London 2000.

${ }^{11}$ T. Kożuchowski, I. Morozow, R. Sawka, Spoteczny wymiar tworzenia filmu w Polsce, Wydawnictwo Biblioteki Państwowej Wyższej Szkoły Filmowej, Telewizyjnej i Teatralnej, Łódź 2019.

${ }^{12}$ Chodzi o spisywane w trakcie realizacji produkcji filmowej przez badaczy (przeszkolonych pod kątem etnograficznym osób pracujących w pionie produkcyjnym) relacje terenowe, opisujące codzienność pracy przy filmie.

${ }^{13}$ Jestem reżyserką pełnometrażowego filmu dokumentalnego Niech inni nie marzna (2016), współfinansowanego przez Unię Europejską ze środków Europejskiego Funduszu Społecznego w ramach programu ,Akademia Rozwoju - kluczem wzmocnienia kadr polskiej gospodarki" oraz współreżyserką będącego obecnie w fazie produkcji średniometrażowego do- kumentu W niewidocznym (reż. G. Hołowiński, I. Morozow, 2019/2020).

${ }^{14}$ A. Kiciński, Rekordowe zainteresowanie polskimi filmami na 16. Millennium Docs Against Gravity, https://www.sfp.org.pl/2016/wydarzenia,92,28837,1,1,Rekordowe-zainteresowaniepolskimi-filmami-na-16-Millennium-DocsAgainst-Gravity.html (dostęp: 17.07.2019).

${ }^{15}$ Wywiad $\mathrm{nr} 2 \mathrm{z}$ producentem $\mathrm{w}$ posiadaniu autorki.

${ }^{16}$ Mam tu na myśli niszowość głównie w odniesieniu do odbioru (przeznaczenia dla wąskiej, specyficznej grupy odbiorczej) i kwestii produkcyjno-dystrybucyjnych (mniejsze budżety, ograniczone kanały dystrybucji i dostępności, niska dochodowość).

${ }^{17}$ Chodzi o filmy produkowane w koprodukcji z co najmniej jednym producentem polskim, $\mathrm{z}$ co najmniej jednym producentem $\mathrm{z}$ siedzibą w Niemczech Środkowych lub w rejonie Berlina-Brandenbrgii.

${ }^{18}$ Programy operacyjne Polskiego Instytutu Sztuki Filmowej na rok 2019, https:/www.pisf.pl/files/dokumenty/po_2019/Programy_Operacyjne_PISF_2019.pdf (dostęp: 19.07.2019).

${ }^{19}$ Wywiad nr 2 z producentem w posiadaniu autorki.

${ }^{20}$ Podstawowym warunkiem udziału $w$ konkursie jest zwiazek projektu z miastem lub regionem poprzez temat filmu, miejsce realizacji lub udziat w produkcji filmu lokalnych osób i firm, a także wydatkowanie co najmniej 100\% (w niektórych regionach 150\%) otrzymanego wsparcia $w$ regionie. http://filmcommissionpoland.pl/pl/finansowanie/fundusze-regionalne/ (dostęp: 19.07.2019).

${ }^{21}$ Zob. http://filmcommissionpoland.pl/pl/finansowanie/eurimages/ i http://filmcommissionpoland.pl/pl/finansowanie/creative-europe/ (dostęp: 19.07.2019).

${ }^{22}$ Zob. A. Wróblewska, Forum Dokumentu i Animacji (cz. I). Czego szukaja nadawcy?, https://www.sfp.org.pl/2016/wydarzenia,5,28825,1,1,-.html (dostęp: 19.07.2019).

${ }^{23}$ Stan na 19.07.2019 r. - 22593 953; Tylko nie mów nikomu, reż. T. Sekielski, https://www.youtube.com/watch? $\mathrm{v}=$ BrUvQ3 W3nV4\&t=1s (dostęp: 19.07.2019).

${ }^{24}$ Poza moim debiutanckim filmem, w podobny sposób był również finansowany inny antropologiczny dokument Żeby to byto ciekawe... O mediatyzacji obrzędów weselnych w reżyserii Karoliny Dudek i Sławomira Sikory, zrealizowany w ramach projektu Analiza roli filmowca i znaczenia filmu weselnego we wspótczesnej kulturze typu ludowego $\mathrm{z}$ grantu MNiSzW (2008-2009). 
${ }^{25}$ Choć mój film był wyświetlany na trzech publicznych pokazach w Dolnośląskim Centrum Filmowym, Centrum Sztuki Współczesnej w Toruniu oraz w Muzeum Współczesnym Wrocław, to wciąż można uznać to za wewnętrzny obieg.

${ }^{26} \mathrm{Z}$ opisu projektu na stronie: http://doclab.pl/pl_PL/doc-lab/co-to-jest/ (dostęp: 19.07.2019).

${ }^{27}$ Przybliżona liczba wynika z niejednolitej definicji, które z filmów można zaliczyć do krótko- lub średniometrażowych.

${ }^{28}$ Opracowanie własne.

${ }^{29}$ Opracowanie własne.

${ }^{30} \mathrm{~W}$ zestawieniu została ujęta jedna produkcja, która miała premierę w listopadzie 2014 r., jednak okres wyświetlania w kinach przypadał na cały rok 2015 do drugiej połowy kwietnia 2016 r.

${ }^{31}$ Równie mało optymistycznie jawi się eksport polskich filmów dokumentalnych, o czym pisał Krzysztof Kopczyński w cytowanym artykule. Zob. K. Kopczyński, dz. cyt.

${ }^{32} \mathrm{~W}$ kontekście prowokacyjnych sytuacji można wspomnieć choćby o słynnej anegdocie z filmu Pierwsza miłość (1974) Krzysztofa Kieślowskiego, gdzie reżyser ,nasłał” funkcjonariusza milicji na swoich bohaterów. Tego typu historie są omawiane na przykład w książce: Historia polskiego filmu dokumentalnego (1945-2014), red. M. Hendrykowska, Wydawnictwo Naukowe UAM, Poznań 2018.
${ }^{33} \mathrm{Na}$ ten temat m.in. J. T. Caldwell, dz. cyt., s. 39-47.

${ }^{34}$ Dziennik terenowy nr $1 \mathrm{w}$ posiadaniu autorki. Ze względu na niejawny charakter badań etnograficznych informacje, które mogłyby jednoznacznie określić produkcję zostały usunięte lub zakodowane na prośbę autora dziennika. Zachowano pisownię oryginalną.

35 Tamże.

${ }^{36}$ Tamże.

${ }^{37}$ Tamże.

${ }^{38}$ W 2019 r. budżet to 1 mln złotych (fabuła $5 \mathrm{mln}$ ), w tym pojedynczy projekt nie może otrzymać więcej niż 100 tys. złotych dla pełnometrażowych i 70 tys. zł dla średniometrażowych.

${ }^{39}$ Wywiad z producentem nr1 w posiadaniu autorki.

${ }^{40}$ Dziennik terenowy nr $1 \mathrm{w}$ posiadaniu autorki.

${ }^{41}$ Zob. T. Kożuchowski, I. Morozow, R. Sawka, dz. cyt., s. 174-175.

${ }^{42}$ Zob. M. Hammersley, P. Atkinson, Metody badań terenowych, tłum. S. Dymczyk, Zysk i Sk-a, Poznań 2000, s. 127-129.

43 Tamże, s. 129.

${ }^{44} \mathrm{Na}$ temat wynagrodzeń w zamian za informację w terenie piszą M. Hammersley i P. Atkinson; zob. tamże, s. 97.

${ }^{45}$ Wywiad z producentem $\mathrm{nr} 3 \mathrm{w}$ posiadaniu autorki.

${ }^{46}$ Tamże. 